\title{
Políticas extremadas: polarização partidária e questões sociais nos Estados Unidos (1936-2012)
}

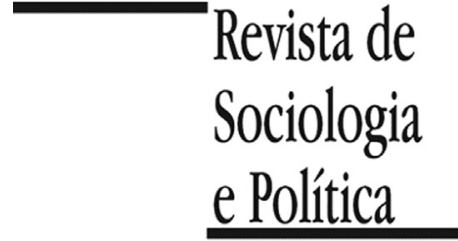

DOI $10.1590 / 1678-987317266505$

\section{Camila Feix Vidal (iD}

RESUMO Introdução: O artigo estuda a polarização política nos Estados Unidos no que se refere às questões sociais entre 1936 e 2012. Por meio do uso de plataformas programáticas em âmbito nacional, o estudo busca verificar a suposta polarização entre os dois principais partidos e contribuir para novas formas de pesquisa nos estudos partidários. Métodos: Foram utilizadas as plataformas programáticas do Partido Republicano e do Partido Democrata como indicativo de posição ideológica. Por meio da construção de categorias e, posteriormente, de escalas de gradação obtidas em programas computacionais como SPSS, ManyEyes/IBM e NVivo, os posicionamentos políticos desses partidos foram mensurados buscando-se verificar aproximações e distanciamentos ideológicos. Resultados: Os resultados nos indicam que, de fato, há uma polarização partidária no período recente no que tange às questões sociais, causada, principalmente, por uma radicalização conservadora republicana iniciada em meados da década de 1970 . Discussão: Fruto de um exaustivo trabalho de leitura, interpretação e codificação de 40 documentos abarcando quase um século de história, o presente artigo contribui para uma melhor apreensão de um fenômeno político e social atual de grande importância na Ciência Política.

PALAVRAS-CHAVE: polarização ideológica; conservadorismo; Estados Unidos; Partido Republicano; Partido Democrata.

Recebido em 24 de Janeiro de 2017. Aceito em 13 de Maio de 2017.

\section{Introduçãa ${ }^{1}$}

1 Agradecemos aos comentários e sugestões dos pareceristas anônimos da Revista de Sociologia e Política.
E m 1950, o relatório anual da American Political Science Association atentava para a conformidade ideológica dos dois principais partidos nos Estados Unidos, concluindo que "alternatives between the parties are defined so badly that is often difficult to determine what the election has decided even in the broadest terms" (American Political Science Association 1950, p.3). Em busca de um "more responsible two party system", esse mesmo relatório propunha que os partidos refletissem reais opções aos eleitores, posicionandose, assim, de maneira distinta ideologicamente. Esse era o período conhecido como "me too politics" (Fiorina 1999) caracterizado por partidos ideologicamente semelhantes onde facções liberais e conservadoras encontravam e dividiam espaço tanto no partido Republicano, como no Democrata. Esse é também o período do consenso e das políticas centristas e bipartidárias no Congresso norte-americano, que facilitava a implantação de medidas e aprovação de leis (McCarthy, Poole \& Rosenthal 2006), de níveis altos de splitticket voting e de apartidarismo no eleitorado (Levendusky 2009). Como resultado, essa baixa coesão ideológica intrapartidária (inclusive onde vários membros do Congresso votavam mais frequentemente com a oposição do que com seu próprio partido) dava a impressão de fragilidade ao sistema partidário (Sinclair 2006). Não por acaso, afloravam trabalhos que previam o declínio (Crotty 1984; Wattenberg 1998) e até mesmo o fim dos partidos políticos (Broader 1972) e da ideologia (Bell 1980). Também não por acaso, esse mesmo período presenciava a emergência de abordagens racionalistas, em especial a partir da obra de Downs (1999), que explicava e legitimava o atual posicionamento centrista dos partidos políticos. Conforme Fiorina (1999) aponta, o tempo não seria gentil com esses autores. 
${ }^{2}$ O termo "liberal" nesse contexto refere-se à defesa de maior ingerência do governo na imposição de políticas de bem-estar social na esfera econômica e, ao contrário, o distanciamento do governo nas questões sociais e de ordem "privada". O liberalismo, assim, posiciona-se de maneira oposta ao conservadorismo que defende menor atuação do Estado na área econômica e maior ingerência na área social.
Em 2003, Broader (1972), que algumas décadas atrás escrevia “The Party is Over", agora atentava para o "excesso partidário" que contribuía para uma "perversão do sistema representativo de governo" (Broader apud Masket 2012). Também algumas décadas depois do discurso proferido na APSA, o presidente dessa mesma organização, Powel (2012), atentaria para a "incongruência ideológica" entre governo e sociedade e para a crescente polarização partidária que questiona o próprio entendimento lógico que se tem sobre democracia.

De fato, o debate acadêmico atual nos EUA não mais trata do fim da ideologia, mas da ideologia extremada; não mais da fragilidade dos partidos políticos, mas da força desses mesmos; não mais do eleitor mediano, mas da "base"; e, por fim, não mais das políticas centristas, mas das políticas extremadas partidárias. Segundo Fiorina (2014, p.3), “today partisanship, ideology and issue positions go together in a way they did not in the mid 20th century. Issues and ideology used to cross-cut partisan distribution, now they reinforce it". Assim, o debate atual nesse país centra-se em estudos sobre uma suposta polarização partidária. Por polarização entende-se uma separação ideológica entre os campos liberal x conservador e a ida para os seus extremos (McCarthy, Poole \& Rosenthal 2006; Fiorina 2014). Esse mesmo debate busca entender a atual política norte-americana (onde o termo "extreme politics" passou a ser a norma) e redefinir o papel e a importância tanto dos partidos políticos como da ideologia, questionando, portanto, as próprias abordagens teóricas então vigentes. Partido e ideologia, hoje, estão muito mais alinhados do que na geração passada, com o campo liberal sendo representado pelo Partido Democrata e o conservador pelo Partido Republicano ${ }^{2}$. Nesse sentido, uma área recebe destaque: as questões sociais ( $\mathrm{so}$ cial issues) - aspectos morais, religiosos e de âmbito pessoal refletidos pela sociedade tais como: aborto, homossexualismo, orientação sexual, imigração, entre outros.

No entanto, ainda que numerosos, os estudos acerca da polarização partidária possuem algumas lacunas explicativas. Na maioria dos casos, ou se concentram em uma análise de posicionamentos de congressistas (Mann 2014; Poole \& Rosenthal 1985; 1984; McCarthy et al., 2006); ou refletem um senso comum na sua maioria de forma qualitativa e indutiva, que inclui desde a relação entre lideranças e a comparação entre elas; bem como a relação do partido com uma mídia extremada e com eventos específicos (Wolfe apud Hunter \& Wolfe 2006; Mann \& Ornstein 2012; Pierson \& Hacker 1995; Mann 2014; Fiorina \& Abrams 2008; Prior 2013).

Este trabalho parte do pressuposto de que o melhor indicativo da ideologia de um partido em nível nacional é a plataforma nacional partidária: único documento atribuído ao partido e endossado por todos, tácita ou formalmente, onde os posicionamentos políticos e pressupostos ideológicos do partido estão expostos. Para Laver e Garry (2000, p.619), programas partidários "represent a core source of information about the policy positions of political actors". Para Pomper (1967, p.319), “a national party's policy commitments are found in its platform. Adopted by its only meaningful organ, the nominating convention, and presented to the voters as the Presidential election approaches, it most fully represent the party's intentions". Para Robertson (apud Budge, Robertson \& Hearl 1987, p.14), "they are the only direct and clear statements of party policy available to the electorate and directly attributable to the party as such". E, por fim, para D'Alessandro (2013, p.109), "son los unicos enunciados politicos que posuen la entidad legal de ser la voz del partido considerado como un todo" constituindo-se, assim, em manifestações institucionais das concepções filosófico-políticas dos mesmos. Os programas partidários são, em última instância, sinalizações do que o partido pretende implementar uma vez eleito e que, em 
3 Dispensa-se alianças para implementação de agenda própria. Ou se tem maioria ou minoria no Congresso. Caso seja a maioria, o partido tem pouca dificuldade na implementação da sua plataforma política. um sistema bipartidário como é o caso dos Estados Unidos, geralmente são implementadas ${ }^{3}$.

Desse modo, trata-se o fenômeno da polarização partidária como hipótese a ser testada. Entende-se que a força dessa tese depende de uma análise histórica comparada nos posicionamentos e ideologias expostas pelos próprios partidos. Nesse sentido, o objetivo desse trabalho é analisar a suposta polarização partidária no que tange as questões sociais por meio das plataformas nacionais e, como tal, contribuir com o uso de diferentes abordagens metodológicas. A contribuição desse trabalho está, portanto, na tentativa de preenchimento dos hiatos deixados pela literatura especializada a partir de enfoques e empirias distintas. O recorte temporal feito diz respeito ao momento em que os conceitos de "liberalismo" e "conservadorismo", tal como o entendemos atualmente, começavam a ser debatido e construídos no meio acadêmico e político: a partir da instauração do primeiro New Deal, em 1933. No que diz respeito às plataformas nacionais, esse recorte se dá entre 1936 (primeira eleição presidencial pós-New Deal) e 2012.

\section{O ideal Conservardor e o ideal Liberal nos Estados Unidos}

${ }^{4}$ A "ideologia" é entendida aqui de maneira inclusiva, definida como um corpo normativo sobre a natureza do homem e da sociedade, bem como da organização e propósito dessa (Seliger 1976)
A definição de uma ideologia ${ }^{4}$ é, por si só, um trabalho difícil em função da pluralidade de aspectos e de temas, da fluidez com que ela se transforma e do próprio contexto em que está inserida. Obviamente, quando se lida com conceitos tão amorfos como conservadorismo e liberalismo, não se tem a intenção de defini-los de forma estanque. Nada mais são do que abstrações por vezes utilizadas de forma ambígua e bastante flexível, que, no entanto, por conta de processos de reificação, são capazes de dar às pessoas uma certa coesão e base de pensamento.

Assim, pela porosidade e fluidez desse tipo de conceito, o máximo que se pode chegar é a uma definição a mais amparada possível pela literatura especializada, de modo que outros trabalhos que visem fazer esse mesmo tipo de categorização possam encontrar resultados semelhantes. Desse modo, optou-se aqui por uma reconstrução histórica acerca de como esses conceitos surgem e vão sendo moldados ao longo dos anos. O interesse aqui reside, portanto, nos diferentes aportes dados a certos conceitos a partir de determinados atores inseridos em um contexto próprio. É, assim, um estudo da história de um "discurso" político por meio da sua langue (estruturas de linguagem) e da $p a-$ role (atos de fala) que são transmitidos e reiterados sucessivamente (Pocock 2003) e cuja evolução é central na formação de uma "consciência politica" e da própria evolução política (Green 1992, p.2).

É importante, no entanto, apontar as dificuldades desse tipo de abordagem. Em primeiro lugar, esses conceitos não são fixos, ao contrário, estão sempre em transformação, dependendo da conjuntura e dos seus proponentes. Em segundo lugar, não há uma coerência necessária entre as várias vertentes dessas ideologias, em específico no que diz respeito ao conservadorismo norte-americano, que abrange correntes bastante contraditórias. Em terceiro lugar, tanto o liberalismo como o conservadorismo em um determinado momento se tornam "self-sustaining" (Nash 2009), não necessariamente refletindo os preceitos mais antigos de seus formuladores. Ou seja, o movimento se auto-direciona, fazendo com que expoentes mais antigos já não se sintam incluídos nessas mudanças. E, por fim, a própria dificuldade que esse tipo de estudo nos incita: como mensurar e reproduzir de maneira coerente e o mais fiel possível o que são, como diz Rossiter (1962), um "mosaico de opiniões"? De fato, não se pode buscar uma única, satisfatória e abrangente definição de fenômemos tão complexos como conservadorismo e liberalismo. Entretanto, se pode ao menos 
buscar certos eixos (um núcleo) que perpassam tempo e espaço e que seriam responsáveis por dar uma certa forma a essas ideologias.

Nesse sentido, é importante mencionar que apesar do "conservadorismo" e do "liberalismo" serem conceitos e ideologias relativamente novas nos EUA, datando de meados do século XX, sempre existiram vertentes que poderiam hoje ser caracterizadas como liberais ou conservadoras. O próprio debate acerca da organização federal e constitutiva norte-americana já atentava para dois grupos (federalistas e anti-federalistas): um que preconizava a união federal, portanto, com um governo federal com certo escopo de atuação, e o outro que defendia a independência dos estados, portanto, um governo federal mínimo. Ao invés de rótulos como "conservadorismo" e "liberalismo", falava-se em "paternalismo" e "individualismo": o primeiro seria a dependência de um Estado de bem-estar social, enquanto o segundo, a rejeição desse.

Assim, esses conceitos não nascem do nada. São continuações de certas visões de mundo e de filosofias políticas que fizeram parte da história norteamericana. No entanto, passam a ser melhor definidas, justificadas e legitimadas a partir de um determinado momento por conta da atuação de certos atores-chave que buscam, por meio do uso desses rótulos, impor-lhes uma certa caracterização ideológica própria e atrelá-los a um partido político. No caso do liberalismo, a partir de meados da década de 1930, com o governo Franklin Delano Roosevelt (F.D.R.); no caso do conservadorismo, a partir da década de 1950 com o desenvolvimento de um network composto por intelectuais, ativistas e empresários (Vidal 2016).

O entendimento de liberalismo nos EUA é, em primeiro lugar, distinto do entendimento de liberalismo no Brasil ou mesmo na Europa - onde é associado ao liberalismo clássico, portanto à escola austríaca, que privilegia a "mão invisível" do mercado e a não interferência na economia. Nesse país, o liberalismo é a ideologia política atual mais fortemente vinculada com à esquerda do espectro político, portanto, uma ideologia que, ao contrário do laissez faire associado ao liberalismo clássico, defende um amplo escopo de atuação federal na construção de um Estado de bem-estar social. Em segundo lugar, a emergência dessa ideologia deve-se ao papel central desenvolvido por lideranças políticas democratas, em específico, F.D.R. Em terceiro lugar, o liberalismo está diretamente vinculado a problemas de ordem prática. Ou seja, longe de ser uma ideologia que já nasce a partir de certos preceitos e de uma agenda política clara, é o resultado de uma série de tomada de posições frente a assuntos práticos de ordem política - talvez justamente pelo papel desempenhado, não por ideólogos e acadêmicos, mas por líderes partidários na sua construção. Por fim, ainda que a emergência do liberalismo como uma filosofia política esteja diretamente vinculada com o governo F.D.R., ela possui raízes tanto nos movimentos progressistas quanto nos movimentos populistas nos Estados Unidos. Com a presidência de Roosevelt, essas tendências seriam "rebatizadas" com o nome de "liberalismo" sem, no entanto, perder as linhas basilares que definiam esses movimentos, em específico a ênfase na igualdade e no papel do governo para a condução de uma sociedade mais igualitária ${ }^{5}$.

${ }^{5}$ É importante mencionar que o progressivismo nos Estados Unidos comportava uma dimensão moral, ou seja, dentre as suas prerrogativas existiam componentes que buscavam impor uma certa moralidade à sociedade norte-americana, diferentemente do liberalismo.
Desse modo, podemos definir algumas características que dão a ele a forma que atualmente possui: o objetivo está na igualdade (econômica ou social). Nesse sentido, o governo detém um papel de provedor dessa sociedade intervém, portanto, em áreas até então consideradas "privadas" ou locais sem, no entanto, descaracterizar o capitalismo típico estadunidense. Por exemplo, regula relações de trabalho e atuação de corporações, redistribui recursos para os mais necessitados por meio de auxílio financeiro, saúde ou programas de emprego, entre outros; mas não socializa terras ou abole a propridade privada. Assim, o liberalismo nos EUA é caracterizado por uma "mixed economy" ao 
estilo Keynesiano - o governo intervém como um árbitro para direcionar o andamento da economia capitalista e mitigar os seus efeitos negativos na sociedade. Na área social, o liberalismo defende uma certa concepção multicultural, perceptível na preocupação com os direitos das minorias, como afrodescendentes, imigrantes, mulheres ou homossexuais. O liberalismo intervém na esfera social (por exemplo, na questão racial e de gênero) com o objetivo tão somente de assegurar a igualdade formal e a liberdade de escolha.

Ao contrário do liberalismo, que emerge na política como resposta a determinadas questões pontuais e cujos proponentes são facilmente identificáveis, o conservadorismo inicia-se no âmbito externo às instituições políticas por meio do esforço conjunto de intelectuais, empresários e movimentos sociais (Brennan 1995; Critchlow 2007; Aberbach \& Peele 2011; Nash 1996; 2009). Longe de comportar uma única e identificável ideologia, esse movimento compõe-se de várias vertentes, por vezes antagônicas, entre elas o tradicionalismo, o libertarianismo e o intervencionismo autônomo; formando uma espécie de "guarda chuva ideológico" (Nash 2009). Desse modo, devido às suas constantes tensões e contradições, não é possível chegar a uma definição amplamente aceita de conservadorismo, ou mesmo de um "perfeito" conservador (Nash 1996; Aberbach \& Peele 2011).

É importante mencionar que até 1945 não havia uma força intelectual, social ou política conservadora relativamente articulada e coordenada (Nash 1996). É certo que já havia vozes dissidentes em relação ao que começava a ser caracterizado como liberalismo, da mesma forma que havia vozes a favor e contra o “engrandecimento" do Estado federal desde a concepção dos EUA. Essas vozes agrupavam-se em três grandes grupos: os libertários, os tradicionalistas e os anti-comunistas intervencionistas (Nash 1996). No entanto, eram vozes soltas, faltando-lhes uma ideologia própria ou mesmo uma "cola" que as unisse e as fizesse mais identificável e palatável aos olhos da população e mesmo dos partidos políticos.

Essas vozes pouco adentravam na política norte-americana. Desde a eleição de F.D.R., que proporcionou sucessivas vitórias democratas no âmbito federal, o PD trilhava um caminho liberal - cada um dos presidentes empossados por esse partido buscava dar continuidade às práticas do New Deal. De modo não muito contrário, o PR passou a trilhar o mesmo caminho. De fato, o governo de Eisenhower não se distancia demasiadamente dos governos democratas no que diz respeito à política econômica, às questões sociais e mesmo à política externa, onde ambos os partidos passariam a priorizar o internacionalismo multilateral (Thompson 2007; Brennan 1995; Nash 1996; Gifford \& Williams

${ }^{6}$ Segundo Brennan (1995), a ala "liberal" republicana (Eastern Establishment) passou a dominar o partido a partir da década de 1940, o que contribuía para uma "crise de identidade" desse último, haja vista que passava a não se diferenciar em grande escala do seu oponente, o PD.
2012) $)^{6}$. É justamente esse o período considerado "me too politics", onde afloravam trabalhos sobre o fim da ideologia e o fim dos partidos políticos. Ao que parecia, havia, até a década de 1960, uma única tendência ideológica na política norte-americana: o liberalismo. Não sendo o PR um artifício para desafiá-la, coube a indivíduos fora do sistema político norte-americano, descontentes com o rumo que a política norte-americana traçava, o desenvolvimento de uma alternativa, ou seja, uma resposta que contrabalançasse o crescente peso que a ideologia liberal tomava na política e na sociedade estadunidense.

O conservadorismo nasce, assim, como reação ao liberalismo a partir de fins da década de 1950 (Pierson \& Skocpol 2007; Schneider 2009; Nash 1996; 2009; Brennan 1995; Gifford \& Williams 2012; Thompson 2007; Aberbach \& Peele 2011; Himmelstein 1989; Philips-Fein 2009). Ainda que tenha raízes antigas datando da própria formação dos Estados Unidos, essa ideologia, em conjunto com as vertentes que hoje a definem, foi efetivamente "inventada" (Gottfried 2007) ou "construída" (Nash 1996) no período imediatamente poste- 
rior ao fim da II Guerra Mundial, com dois objetivos muito claros: fazer uma contraposição à ideologia dominante (o liberalismo) e "capturar" um partido político com esse fim (o PR) (Gifford \& Williams 2012; Thompson 2007). Assim, há que se notar que não é uma continuação ou uma releitura de Edmund Burke. O conservadorismo norte-americano é bastante diferente do europeu, tanto por sua origem como pelos seus ideais - não é unicamente reacionário, mas, ao contrário, corresponde por vezes a respostas proativas em um mundo em constante mudança (Gifford \& Williams 2012; Thompson 2007).

Esse movimento tem início fora dos partidos políticos a partir do debate que se trava entre intelectuais e acadêmicos insatisfeitos tanto com a ideologia liberal dominante quanto com a "me too politics". No entanto, como argumenta Nash (1996), livros, por si só, não criam um movimento intelectual coeso da mesma forma que ideias por si só, não são suficientes para alterar o rumo da política. Daí a necessidade da construção de uma ampla rede de influência (com a criação de associações, movimentos sociais, revistas e think tanks, por exemplo) com impacto político (Nash 1996; Brennan 1995). Essa construção de networks, por sua vez, só pode ser efetivada com recursos financeiros. Ideias e recursos financeiros, nesse sentido, tornariam-se cruciais para a criação e manutenção do movimento conservador (Philips-Fein 2009). O estudo do conservadorismo norte-americano, desse modo, está intimamente associado com intelectuais (bem como com a construção de revistas e think tanks por esses desenvolvidos), com ativistas (por meio de movimentos sociais) e mesmo com empresários (por meio do "financiamento" desses projetos) (Vidal 2016). Esses indivíduos, assim, construiriam uma ideologia e um movimento baseado, ao fim, em três pilares: na economia, uma aversão ao Estado de bem-estar social que representava o New Deal; nas questões sociais a retomada da moralidade, das tradições e da religião; e na política externa, o combate ao comunismo por meio de uma política intervencionista unilateral. Esses três elementos permanecem até hoje como as bases dessa ideologia: o libertarianismo, o tradicionalismo e o anticomunismo militante (Himmelstein 1989). O ponto central do fusionismo (síntese das vertentes conservadoras), é o entendimento de que a preocupação libertária com a liberdade individual e a preocupação tradicionalista com a moralidade e a religião, longe de serem antagônicas, faziam parte de uma mesma filosofia política.

Assim, o conservadorismo é, em primeiro lugar, uma reação contra o liberalismo. Para os libertários, o liberalismo significa um governo federal cada vez maior, associando-se a um estado totalitário, que retira parte da propriedade privada do indivíduo para redistribuição e para manutenção do seu aparato burocrático. Para os tradicionalistas, o liberalismo significa a erosão dos valores cristãos e da tradição norte-americana. É a desintegração da família tradicional, é a erosão do papel dos pais como educadores, a desestruturação das funções tradicionais desenvolvidas por homens e mulheres, o comportamento "libertino" etc. Já para os intervencionistas militaristas, o liberalismo é a capitulação dos Estados Unidos frente ao mundo externo. É o enfraquecimento da sua soberania frente a acordos e organismos internacionais e do próprio território nacional frente a políticas de appeasement.

Em resumo, na área econômica o conservadorismo é, sobretudo, libertário. Valoriza o laissez faire, a iniciativa privada e um governo federal com escopo de atuação mínimo. Defende o "mérito" e a propriedade privada como um bem supremo, portanto, acredita que impostos devem ser mínimos e não progressivos. Essa é a sua concepção de justiça. Essa característica está muito visível na área social. O conservadorismo valoriza uma certa hierarquia em todos os sentidos: familiar, social, econômica etc. Como já atentava Kirk, é a diferença entre o escalão da frente e o de trás a força motriz do progresso. Essa hierarquia obviamente tem raízes nas tradições - assim, depreende-se a não interferência 
em questões raciais bem como a hierarquia do empregador referente ao empregado ou mesmo do pai frente ao filho. A utilização da religião como forma de justificativa e legitimação dessas questões é facilmente verificada nessa área. Em praticamente todos os aspectos, há uma menção implícita ou explícita a uma certa ordem divina: o homem e a mulher são diferentes porque detêm funções distintas; ao pobre foram colocados percalços para que obtenha por ele próprio uma redenção futura; a vida é uma dádiva divina; enfim, a religião e a tradição são as diretrizes conservadoras no que diz respeito às questões sociais conforme caracterização do Quadro 1.

\section{Apresentação do modelo de análise: variáveis, categorias e formas de mensuração}

De maneira geral, a análise de plataformas partidárias está inserida em uma metodologia ampla de análise de conteúdo; no entanto, vem sendo progressivamente estruturada de maneira a abarcar diferentes métodos no estudo de textos partidários. A evolução pela qual passa a análise de plataformas pode ser resumida da seguinte maneira: 1 ) desconstrução do texto de maneira estrutural por meio de parágrafos, temas ou frases, buscando-se perceber a sua estruturação, ênfases e a linguagem; 2) desconstrução do texto de maneira mais sistemática e em menores fragmentos, buscando-se correlações com categorias pré-definidas em um processo de handconding; 3) mais recentemente, o uso de palavras como dados por meio de programas de computação desenvolvidos com esse fim. Na maioria dos casos, a análise de plataforma é feita de maneira comparada, buscando correlações com outras plataformas ou manifestos partidários. O trabalho aqui proposto visa utilizar essas técnicas na análise das plataformas nacionais Republicanas e Democratas, utilizando, para isso, de programas e softwares como o SPSS, NVivo e ManyEyes/IBM para a construção de scores de quantificação.

Nesse sentido, a abordagem assemelha-se aos moldes da escala desenvolvida por Feinstein e Schickler (2008), Koster, Achterberg e Van Der Wall (2012) e Lange (2007). Assim, são pontuados posicionamentos explicitados na plataforma de acordo com uma escala que visa verificar a presença de preceitos conservadores e liberais, bem como analisar a inflexão desses posicionamentos

Quadro 1 - Oposição entre liberalismo e conservadorismo norte-americano referente às questões sociais

\begin{tabular}{lll}
\hline & Conservadorismo & Liberalismo \\
\hline Ênfases & Hierarquia & Igualdade \\
& Família e comunidade & Indivíduo \\
& Religião e moralidade Cristã (inclusive na esfera & Não faz menção à religião ou à moralidade Cristã \\
& pública) & - (circunscrito à esfera privada) \\
& Tradição & Inovação \\
Papel do governo & Deve refletir a religião e a moralidade cristã e & É laico: deve servir de rede de proteção à socieda- \\
federal & impor-la na sociedade: o governo, assim, tem o & de mas não tem o papel de condutor dessa nas \\
& dever de conduzir a sociedade & questões de ordem pessoal \\
Cultura & Enfatiza o nacionalismo & Enfatiza o multiculturalismo \\
Temas mais & -Movimento Civil Rights: contra, segregação é & -Movimento Civil Rights: a favor, defesa da \\
enfatizados & permitida; & igualdade de direitos; \\
& - Pro-life (contra a legalização do aborto); & -Pro-choice (a favor da legalização do aborto); \\
& - Contra a legalização de direitos para & -A favor da legalização de direitos para \\
& homossexuais (casamento, por ex.); & homossexuais (casamento, por ex.); \\
& -Contra orientação sexual nas escolas; & -A favor de orientação sexual nas escolas; \\
& -Contra políticas emancipatórias, afirmativas e/ou & -A favor de políticas emancipatórias, afirmativas \\
& feministas (ênfase está na manutenção da família). & e/ou feministas (ênfase está na liberdade individual). \\
\hline
\end{tabular}

Fonte: A autora, com base nas plataformas dos Partidos Democrata e Republicano. 
ao longo do tempo em uma espécie de escala de gradação. É importante mencionar que essa análise possui uma certa semelhança com o método de codificação manual desenvolvido pelo Manifest Research Group; no entanto, não é uma releitura ou continuação dessa. Ao contrário, a abordagem aqui escolhida possui importantes diferenças.

Em primeiro lugar, o foco não está na saliência, mas no confronto. Entende-se que os partidos não possuem temas "próprios" e com isso os exploram em detrimento de outros. O que esse estudo feito nos mostra é que os temas de maior repercussão e de maior polarização ideológica nascem de eventos na sociedade - como é o caso do aborto (Roe x Wade) e Civil Rights (Brown x Board of Education) por exemplo, ao qual os partidos acabam por se posicionar sem, no entanto, manter a "propriedade" do tema em questão. A abordagem aqui feita, portanto, busca quantificar o posicionamento partidário expresso na plataforma a partir das categorias específicas e da presença dessas ou não na plataforma. Pouco importa quantas vezes foi mencionada a opção pro-choice no que diz respeito ao aborto; o interesse reside SE e COMO ela foi mencionada (retórica, mudanças legislativas, procedimento público etc.).

Em segundo lugar, foge-se do uso "a favor" e "contra" tal como exposto no MRG. São poucos os temas em que se poderia definir o liberalismo e o conservadorismo a partir dessa dicotomia. Não se pode supor, por exemplo, que por contar com o apoio liberal, o conservadorismo seja "contra" o movimento Civil Rights. O conservadorismo, tal como uma ideologia composta de certos preceitos, diz-se contrário a ingerência federal nesse assunto, mas isso não pressupõe que seja contrário ao movimento como um todo. Daí a opção nesse trabalho por desenvolver categorias mais específicas e consoantes com o liberalismo e o conservadorismo norte-americanos.

Em terceiro lugar, buscou-se categorizar também a abstenção do partido acerca de um tema já pautado no debate político atribuindo-lhe um posicionamento centrista e o " 0 ” na sua quantificação, por entender que a recusa em posicionar-se acerca de um tema é também uma escolha - nesse caso, centrista. Essa recusa em posicionar-se, por fim, foi contabilizada como 0 na média feita com os outros indicadores.

Por fim, buscou-se ainda fazer uma análise que levasse em conta o momento em que a plataforma foi escrita (Quadro 2), haja vista a complexificação das plataformas e aumento de seu escopo (Tabela 1). Ou seja, utilizar-se das categorias e quantificá-las a partir de uma seleção prévia que contemple os temas naquele cenário político. O tema do aborto, por exemplo, só passa a fazer parte do debate político recentemente, de modo que seria incorreto contabilizá-lo na análise das primeiras plataformas. A linha do tempo desenvolvida nesse trabalho (Quadro 2) busca esclarecer justamente quando determinados temas surgiram no debate político e poderiam então passar a ser analisados e quantificados nas plataformas ${ }^{7}$. Assim, faz-se o seguinte calculo: P/T, onde P é a somatória dos pontos em uma dada plataforma e $\mathrm{T}$ é a somatória dos temas parte do debate político na época perfazendo, desse modo, uma média aritmética. A relação dos indicadores empregados em cada tema está no apêndice 1.

\section{Análise das plataformas: Partido Republicano}

Como se pode verificar no Gráfico 1, o PR possui dois ápices invertidos: em um primeiro momento, entre 1936 e 1972, o PR está consistentemente posicionado no campo liberal; enquanto entre 1976 e 2012 ele move-se para o campo conservador, onde aí permanece. Antes de adentrar na análise descritiva sobre esses dois períodos, convém ressaltar dois pontos. Em primeiro lugar, há um aumento de temas e posicionamentos defendidos pelo partido ao longo dos anos 
Quadro 2 - Linha do tempo - temas e partidos

\begin{tabular}{|c|c|c|}
\hline Ano & Partido Republicano/Temas & Partido Democrata/Temas \\
\hline 1936 & Questão Racial & Comunismo \\
\hline 1940 & $\begin{array}{l}\text { Feminismo e Gênero (Equal Rights } \\
\text { Ammendment -ERA) } \\
\text { Imigração }\end{array}$ & Questão Racial - Civil Rights \\
\hline 1944 & & ERA \\
\hline 1948 & Comunismo & Imigração \\
\hline 1952 & $\begin{array}{l}\text { Civil Rights Child } \\
\text { Care }\end{array}$ & Child Care \\
\hline \multicolumn{3}{|l|}{1956} \\
\hline \multicolumn{3}{|l|}{1960} \\
\hline 1964 & Religião & \\
\hline 1968 & $\begin{array}{l}\text { Armas de Fogo } \\
\text { Drogas }\end{array}$ & $\begin{array}{l}\text { Armas de Fogo } \\
\text { Drogas } \\
\text { Educação - currículo }\end{array}$ \\
\hline \multicolumn{3}{|l|}{1972} \\
\hline 1976 & $\begin{array}{l}\text { Aborto } \\
\text { Família (valores, comunidade) }\end{array}$ & Aborto \\
\hline \multicolumn{3}{|l|}{1980} \\
\hline 1984 & $\begin{array}{l}\text { Educação - currículo e valores } \\
\text { Gravidez na adolescência } \\
\text { Entretenimento }\end{array}$ & $\begin{array}{l}\text { Homossexualismo } \\
\text { Entretenimento }\end{array}$ \\
\hline 1988 & AIDS & AIDS \\
\hline 1992 & Homossexualismo & $\begin{array}{l}\text { Gravidez na adolescência } \\
\text { Família (valores, comunidade) }\end{array}$ \\
\hline 1996 & Defense of Marriage Act (DOMA) & $\begin{array}{l}\text { Religião } \\
\text { Educação - valores }\end{array}$ \\
\hline \multicolumn{3}{|l|}{2000} \\
\hline \multicolumn{3}{|l|}{2004} \\
\hline \multicolumn{3}{|l|}{2008} \\
\hline 2012 & & \\
\hline
\end{tabular}

Fonte: A autora, com base nas plataformas dos Partidos Democrata e Republicano.

- inicialmente o debate dentro das questões sociais restringia-se à questão de descriminação, como no debate sobre negros, gênero ou imigrantes. Posteriormente, novos temas surgem e demandam um posicionamento do partido, tal como aborto, homossexualismo, pornografia e entretenimento. Por fim, um segundo ponto a mencionar é a percepção de que os temas podem ser divididos, eles também, em dois momentos: um primeiro momento, até a década de 1980, onde a ênfase está nas questões de discriminação e extensão de direitos relativos a mulheres e a negros, por exemplo; e um segundo, a partir da década de 1980, onde novos temas com um tom mais moralizante passam a pautar o debate. Nota-se, nesse segundo momento, a perda de espaço nas plataformas dessas temáticas iniciais até serem completamente desprezadas, como é o caso da questão racial e de gênero.

Entre 1936 e 1972 pode-se dizer que o PR, no que concerne às questões sociais, podia ser caracterizado como um partido majoritariamente liberal. Até a década de 1960, o PR se concentraria em temas relativos ao movimento civil rights, emancipação feminina, imigração e no debate relativo às cotas. Nesse 
Tabela 1 - Tamanho das plataformas a partir da contabilização de palavras

\begin{tabular}{lcc}
\hline Ano & Partido Democrata & Partido Republicano \\
\hline 1936 & 2.310 & 3.030 \\
1940 & 4.667 & 3.284 \\
1944 & 1.366 & 4.216 \\
1948 & 4.256 & 2.739 \\
1952 & 8.878 & 5.988 \\
1956 & 12.839 & 11.390 \\
1960 & 16.098 & 10.680 \\
1964 & 20.126 & 8.740 \\
1968 & 16.791 & 10.013 \\
1972 & 25.615 & 24.407 \\
1976 & 21.202 & 20.463 \\
1980 & 38.180 & 34.558 \\
1984 & 37.231 & 27.408 \\
1988 & 4.838 & 36.250 \\
1992 & 8.555 & 28.536 \\
1996 & 18.098 & 27.817 \\
2000 & 24.220 & 34.679 \\
2004 & 17.751 & 41.414 \\
2008 & 25.997 & 23.650 \\
2012 & 26.555 & 30.562 \\
\hline
\end{tabular}

Fonte: A autora, com base nas plataformas dos Partidos Democrata e Republicano.

8 "Equal pay for equal work"; ou seja, salários iguais para trabalhos iguais. momento, há uma certa manutenção no posicionamento do partido que privilegia noções de igualdade. No caso de gênero, valoriza-se não só a extensão de direitos às mulheres e a defesa do $\mathrm{EPEW}^{8}$, mas também de emenda à Constituição, garantindo direitos iguais entre homens e mulheres (Equal Rigths Amendment - ERA) demonstrando, assim, a prevalência de um posicionamento liberal que defende o papel do governo federal na instauração de certos direitos civis. Do mesmo modo, no que tange à questão racial, o partido defende uma ampla interferência federal para a garantia de direitos e na legalização desses, como sufrágio universal, a criminalização de práticas de descriminação e de

Gráfico 1 - Média questões sociais - Partido Republicano

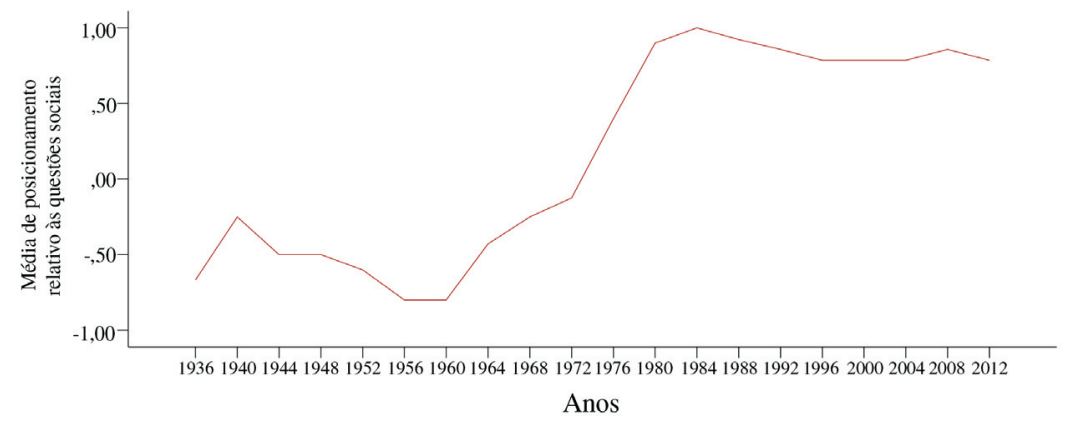

Fonte: A autora, com base nas plataformas dos Partidos Democrata e Republicano. 
linchamento e mesmo a não segregação nas escolas públicas - instituição tipicamente de responsabilidade estadual. A plataforma de 1960, por exemplo, destina grande parte do seu espaço para a questão racial reiterando o caráter "injusto e imoral" da descriminação racial e intensifica a crítica à segregação. O partido demonstra, assim, não só a defesa de um papel ativo do governo federal na extensão de direitos, mas também a defesa da ingerência federal em legislações estaduais e locais contrariando um importante preceito conservador atrelado ao federalismo. Há o entendimento de que, ainda que se valorize o federalismo, existem certas questões que, caso não respeitadas pelas entidades locais, decorre a necessidade de intervenção federal. Nesse momento, há ainda o entendimento de que cotas e tratamento preferencial são instrumentos necessários para maior igualdade. No que tange à imigração, o discurso baseia-se majoritariamente na valorização dos imigrantes como responsáveis pela "grandeza" estadunidense, enfatizando-se a igualdade de tratamento e a concessão de asilo a refugiados. Em 1960 defende-se, por exemplo, a duplicação do número de imigrantes aceitos no país e uma maior "solidarização" com refugiados e com os "oprimidos".

A partir de 1964, novos temas surgem nas plataformas republicanas. Nessa mesma plataforma, verifica-se pela primeira vez a relação entre a religião e os espaços públicos. Ao defender o direito do exercício da religião em locais públicos, mas reiterando e enfatizando a necessidade de se manter a separação entre Estado e religião, o partido posiciona-se próximo ao espectro liberal. Nessa plataforma, há ainda a manutenção dos posicionamentos relativos à questão racial e imigração (pela primeira vez defende-se a idéia de reunificação familiar para imigrantes). Já em 1968, a plataforma apresenta o debate sobre a posse de armas de fogo defendendo um posicionamento tipicamente liberal - a defesa de controle a partir de regulações federais. Esse ponto é interessante porque essa é a primeira vez que o debate sobre o tema aparece nas plataformas republicanas e também a única vez em que o partido iria se posicionar de modo liberal.

De fato, a partir da plataforma de 1972, nota-se o início da inflexão conservadora. Nessa plataforma, há a primeira inversão de posicionamentos no que diz respeito às questões raciais: o partido argumenta ser contrário a transposição de "crianças negras" para "escolas brancas" numa espécie de "equilíbrio racial" (racial balance) em "respeito" à localidade onde a criança está inserida. Também pela primeira vez se critica a política de cotas ou de tratamento preferencial para minorias em universidades: "We believe the imposition of arbitrary quotas in the hiring of faculties or the enrollment of students has no place in our universities; we believe quotas strike at the excellence of the universities" (Partido Republicano 1972). Há uma mudança de posicionamento no que diz respeito ao porte de armas, agora um posicionamento conservador que defende o direito de "responsible citizens" de possuir, colecionar e usar armas de fogo. Ainda assim, a plataforma de 1972 mantém importantes posicionamentos liberais como na questão de gênero (inclusive sendo exaustiva na defesa da criação de child care facilities financiadas pelo governo federal), da religião (atentando para a separação entre religião e Estado) e da imigração (defendendo a prática do "open doors" para entrada de imigrantes e financiamento de projetos bilíngues que obriguem departamentos públicos a atenderem em inglês e espanhol).

Enquanto a plataforma de 1972 pode ainda ser considerada relativamente ambígua ideologicamente, contemplando posicionamentos conservadores e liberais ao mesmo tempo; a plataforma de 1976 e todas as outras que iriam se seguir demonstram a prevalência do conservadorismo. Esse segundo momento define-se por uma variedade de temas relativos a questões sociais e uma maior preocupação com aspectos “morais”. A plataforma de 1976 traz, por exemplo, a 
preocupação republicana com uma suposta ruptura da estrutura familiar na sociedade e com práticas de aborto. Relativo a esse último ponto, é importante mencionar que, ainda que o partido defenda uma posição pró vida, portanto conservadora, é possível verificar as diferentes facções ideológicas que naquele momento ainda permeavam dentro do partido. De fato, é só a partir de 1980 que as plataformas republicanas iriam posicionar-se consistentemente no campo conservador no que diz respeito às questões sociais, suscitando uma mudança intrapartidária - agora mais homogênea ideologicamente.

Nesse segundo período, as questões raciais e de gênero vão perdendo espaço nas plataformas até serem eliminadas do debate. A partir de 1980, o partido passa a defender a igualdade de direitos sem interferência federal, valorizando, para isso, legislações estaduais e o papel do livre mercado, que supostamente propiciaria oportunidades iguais. $\mathrm{O}$ partido mantém-se contrário às cotas e tratamentos preferenciais: mérito, habilidade e resultados devem ser os fatores que determinam o avanço na sociedade. A questão do child care a partir de financiamento federal, bastante valorizada em plataformas anteriores, passa a ser rejeitada, dando ênfase a um maior leque de "oportunidades" aos pais "opções" que incluam cuidado de crianças pelos vizinhos, familiares, igrejas, empregados e setor privado.

No que diz respeito à imigração, ao aborto e ao homossexualismo, nota-se posicionamentos cada vez mais críticos. Relativo ao primeiro ponto, as plataformas passam a defender a necessidade de proficiência em inglês (invertendo o posicionamento anterior, quando se defendia tratamento bilíngue em departamentos públicos) e de controle das fronteiras. A plataforma de 1996 é uma das que mais enfatiza a questão da imigração. Nela, argumenta-se a necessidade de deportações mais rápidas, de diminuição da entrada de imigrantes em "manageable levels", de penalidades mais severas para quem estender seu visto, do fim de benefícios dados a ilegais e imigrantes legais (que devem depender dos seus sponsors) e legislação que proíba a cidadania para crianças nascidas nos Estados Unidos de pais ilegais. Por fim, em 2004, a imigração passa a ser um assunto tratado a partir de um viés de segurança nacional. A plataforma de 2012, por exemplo, relaciona um alto número de imigrantes ilegais com um maior risco de atentados terroristas, tráfico de drogas e crimes.

Relativo ao aborto, passa-se a defender desde uma emenda à Constituição que garanta os direitos do feto (a partir de 1980) e o fim do financiamento federal para aborto ou para organizações que defendem aborto (a partir de 1984); até a valorização do papel das instituições privadas e religiosas que oferecem outras alternativas, como adoção (a partir de 1984). Já com relação ao homossexualismo, o partido passa a defender o fim dos "direitos especiais" (tal como casamento e adoção) a partir da plataforma de 1992, advogando, já em 2004, uma emenda constitucional que "proteja" a instituição do casamento como uma união entre um homem e uma mulher. Nesse sentido, enfatiza-se a manutenção da família tradicional e do casamento entre homem e mulher, seja por meio de projetos como o DOMA (Defense of Marriage Act), seja na defesa de legislações mais duras que dificultariam o divórcio. A partir da plataforma de 1992, as plataformas passam a reiterar a valorização de estruturas familiares com um pai e uma mãe como o melhor ambiente para a criação de crianças.

Nesse segundo momento, há também a valorização da educação "back to basics", bem como da disciplina e da moralidade nas escolas. A partir de 1988, as plataformas passariam ainda a defender que a Pledge of Alliance fosse recitada diariamente nas escolas públicas. A escola passa a ser o ambiente, assim como a família, onde se ensina "right from wrong" (1992). A plataforma de 1996 defende ainda a obrigação das escolas de ensino fundamental e médio de dedicarem um dia por ano ao estudo da Constituição Federal e da Declaração 
da Independência, uma tentativa de valorização da nação e da tradição, preceitos tipicamente conservadores.

Temas como gravidez na adolescência e o papel da escola na educação sexual passam a ser enfatizados a partir de uma lógica também bastante conservadora. Se privilegia programas federais que "ensinem" a abstinência sexual até o casamento e a fidelidade matrimonial "as the expected standard of behavior" (1996). A partir da plataforma de 1988, o partido passa a defender a necessidade de consentimento dos pais para o uso de contraceptivos e a valorização de programas como Adolescent Family Life que "ensina" os jovens os "valores tradicionais da castidade e da santidade do casamento" (1988). Em 2004, defende-se, inclusive a duplicação de recursos federais enviados à programas educacionais que "ensinem" a abstinência para jovens; e, em 2012 defende-se a proibição da venda de remédios que impeçam a gravidez indesejada.

Notadamente, há uma preocupação com a “imoralidade” na mídia por conta de pornografia, da "glorificação da violência" e "glamourização das drogas" por meio da televisão e do cinema (2000). Em 1988, a plataforma argumenta a necessidade de legislação federal que garanta um "nível de decência" nas telecomunicações. Na plataforma seguinte, em 1992, iria propor uma "national crusade" contra a pornografia, defendendo, inclusive, legislação federal que proíba a venda desse tipo de material.

Nesse segundo momento, a religião e as instituições religiosas desempenham um maior protagonismo nas plataformas. Há uma tentativa de reverter a suposta "war on religion" (2012) perpetuada por liberais democratas. A religião e a moralidade, assim, passam a ser tratadas não mais em separado do Estado e da política, mas fundamentalmente como o mais importante pilar que sustenta ambos. As plataformas passam não só a defender o direito da prática da religião em público, como também passam a posicionar-se contra o banimento de símbolos religiosos em espaços públicos (a partir da plataforma de 1996). A partir da plataforma de 2000, seria defendido ainda a obrigação da exposição dos Dez Mandamentos em prédios e lugares públicos. O partido passaria a defender, também, a independência de instituições religiosas, tal como hospitais e escola, para recusarem a atender ou admitir membros não religiosos, posicionando-se de forma contrária ao julgamento da Suprema Corte.

Desse modo, ao contrário de abstenção federal, o Partido Republicano acaba por valorizar uma crescente interferência e papel de amplo escopo na sociedade. Nesse sentido, as questões sociais são permeadas pela ênfase na moralidade nacional e no dever do Estado de promovê-la. A plataforma de 1992 é emblemática nesse ponto: "Government has a responsibility to ensure that it promotes the common moral values that bind us together as a nation". Por fim, 2012, afirmaria: "democracy presupposes a moral people".

\section{Análise das plataformas: Partido Democrata}

As plataformas democratas podem ser divididas em três períodos, conforme o Gráfico 2: um primeiro momento, entre 1936 e 1992, caracterizado como um período genuinamente liberal - salvo o hiato de 1964; um segundo, entre $1996 \mathrm{e}$ 2004, definindo-se a partir de uma inflexão conservadora; e, por fim, entre 2008 e 2012, caracterizado pelo retorno ao liberalismo.

O primeiro momento apresenta como temas mais recorrentes no período inicial a questão de gênero, a imigração e as questões raciais. Posteriormente, seriam incluídos temas como aborto, homossexualismo, posse de armas de fogo, entre outros. Com exceção da plataforma de 1964, que faz uma leve inflexão conservadora, as plataformas nesse período se caracterizam pela defesa de posicionamentos liberais típicos. 
Gráfico 2 - Média Questões Sociais - Partido Democrata

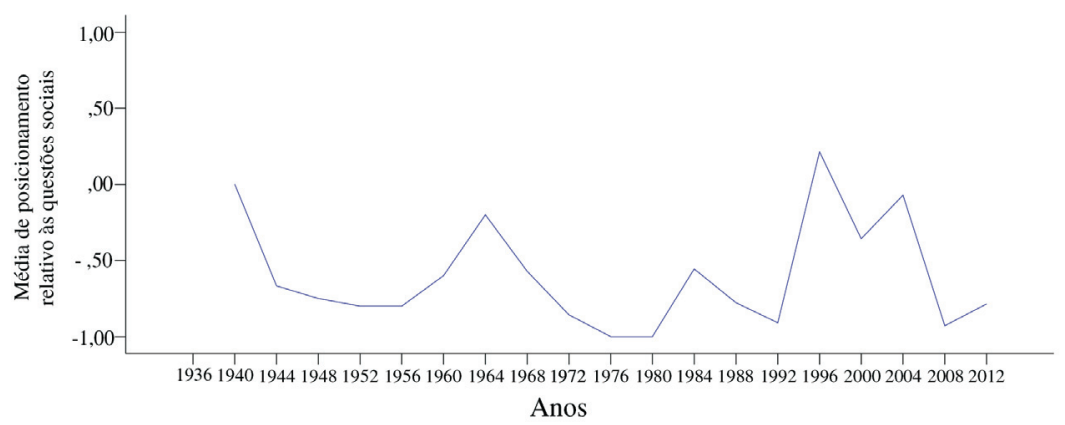

Fonte: A autora, com base nas plataformas dos Partidos Democrata e Republicano.

O debate acerca do gênero, mais especificamente acerca da emancipação feminina, inicia-se a partir de 1940 quando essa plataforma advoga direitos iguais, particularmente no que diz respeito ao direito de trabalho. Em 1944, o partido passaria a defender, consistentemente em suas plataformas, a submissão, ao Congresso, de uma emenda constitucional de direitos iguais para mulheres. Em 1972 passaria também a defender benefícios para a maternidade (como licença maternidade) e maiores direitos nas forças armadas. A questão acerca do child care, por fim, insere-se a partir dessa mesma lógica acerca da emancipação feminina. A partir de 1952, as plataformas (com exceção de 1964) passariam a defender um papel ativo do governo federal no cuidado de crianças, por meio de instituições próprias, para que as mães pudessem trabalhar fora e, assim, exercer plenamente seus direitos.

Já o debate acerca da questão racial e dos civil rights inicia-se em 1940, quando o partido defende salvaguardas legislativas contra a descriminação no âmbito federal. A partir de 1944, o partido passaria a defender o direito de voto aos afrodescendentes - uma questão sensível, já que interfere em leis locais e estaduais. Já em 1956, a plataforma defenderia a decisão da Suprema Corte contra a segregação racial nas escolas. É importante mencionar que o debate acerca dos civil rights nem sempre foi genuinamente liberal. Em 1964 há uma crítica à política de cotas para afrodescendentes como meio de reparar danos causados pela segregação. O partido, nesse sentido, posiciona-se contra o que chama de "discriminação reversa". É bom lembrar que nesse momento o partido democrata ainda detinha uma posição privilegiada no sul dos Estados Unidos - o chamado "democratic south". Daí a defesa de legislações que buscassem estender direitos iguais, mas não "mais" direitos. Assim, nesse momento inicial, a ênfase refere-se basicamente à não descriminação e ao direito de voto. $\mathrm{O}$ posicionamento contrário às cotas seria revertido nas plataformas seguintes. Em 1976, por exemplo, o partido afirma: "We pledge vigorous federal programs and policies of compensatory opportunity to remedy for many Americans the generation of injustice and depravation". O objetivo do partido democrata nessa questão, passa a ser maior integração social e econômica.

Relativo ao debate acerca das cotas e tratamento preferencial para minorias, é preciso enfatizar que, na primeira vez em que o partido se posiciona acerca do tema (1964), ele posiciona-se de modo contrário à política de cotas. Refletindo um posicionamento tipicamente conservador, afirma: "True democracy of opportunity will not be served by establishing quotas based on the same false distinctions we seek to erase, nor can the effects of prejudice be neutralized by the expedient of preferencial practices". Esse, no entanto, seria o primeiro e o único momento desse primeiro período em que o partido se oporia à política de cotas. 
A partir da plataforma seguinte, há a defesa constante de tratamento preferencial para minorias. A partir de 1972 o partido passaria a defender, também, maiores oportunidades para educação de mulheres e "grupos subrepresentados": em 1976, defende a promoção de minorias para cargos diplomáticos e para juízes federais e, em 1980, incentivos federais para maior aquisição de negócios e empreendimentos por minorias por meio de empréstimos, treinamento e regulações favoráveis.

No que tange à imigração, o PD defende, nesse primeiro momento, a entrada de um número maior de imigrantes. Na plataforma de 1948, defende-se a admissão de 400 mil refugiados pela guerra e a distribuição de cidadania automática. Na plataforma seguinte, mantém-se esse posicionamento, mas inclui-se os refugiados soviéticos alegando o caráter positivo da imigração: "The gates must be left open for practical numbers of desirable persons from abroad whose immigration to this country provides an invigorating infusion into the stream of American life" (1952). A partir de 1956, as plataformas passariam, também, a defender a reunificação familiar. Há nesse período uma preocupação com a divisão entre imigrantes (e cidadãos naturalizados) e norteamericanos nativos: "We want no second class citizens in America" (1952). Nesse sentido, defende-se serviços federais bilíngues como tentativa de facilitar a ascensão dos imigrantes na sociedade norte-americana (1968) além de programas educacionais "biculturais", educação adulta bilíngue (1972) e uma maior facilidade de aquisição de cidadania (1976). Por fim, valoriza-se a diversidade e os benefícios sociais que uma política de acolhimento de imigrantes traria aos Estados Unidos.

Essa defesa da diversidade é também percebida nos posicionamentos democratas acerca da educação. A partir da década de 1970, quando o tema começa a ser colocado em pauta nas plataformas, o PD passa a posicionar-se a favor de maiores políticas e programas educacionais de valorização da diversidade e da integração. A plataforma de 1972, por exemplo, advoga maiores recursos para estudos étnicos por meio do desenvolvimento de um currículo que reflita o "mosaico" étnico norte-americano. Em 1972 argumenta que a escola tem o papel de criar um sentimento de unidade nacional e de reconciliar conflitos étnicos, religiosos e raciais. A partir dessa mesma plataforma, seria recorrente a defesa de maiores programas educacionais bilíngues e "biculturais" em escolas públicas. Por fim, em 1980, defende-se uma prática educacional que valorize diferentes culturas, línguas e países.

De fato, durante todo esse primeiro momento, há a valorização da diversidade étnico cultural. Palavras como "mosaico" e "melting pot" são recorrentes. Há ainda a valorização da unidade nacional por meio do reconhecimento da diversidade. O partido posiciona-se de maneira contrária à uniformização ou padronização: "America is a pluralist society. Each of us must learn to live, communicate, and cooperate with persons of other cultures. Our public policies and programs must reflect this pluralism" (1980).

Na plataforma de 1976, surge a questão do abordo. Nesse momento não haveria uma defesa ao direito de abortar, mas tão somente a aceitação da decisão da Suprema Corte: "We fully recognize the religious and ethical nature of the concerns which many Americans have on the subject of abortion. We feel, however, that it is undesirable to attempt to amend the US constitution to overturn the SC decision in this area" (1976). No entanto, na plataforma seguinte, o posicionamento do partido acerca do tema passa a ser mais decisivo: "The Democratic Party supports the 1973 Supreme Court decision on abortion rights as the law of the land and opposes any constitutional ammendment to restrict or overturn that decision" (1980). Já em 1992, o partido passa a valorizar a "escolha" como uma questão de direito. Pela primeira vez, defende uma lei fed- 
eral para garantir o direito ao aborto independente de condições financeiras para realizá-lo. A ênfase recai no direito pessoal, ou seja, não seria papel do governo intervir, mas tão somente proteger esse direito. Por fim, nessa mesma plataforma, o partido se posicionaria, ainda, a favor de educação sexual, aconselhamento, acesso a contraceptivos e direito ao aborto no caso de gravidez indesejada na adolescência.

Relativo ao debate acerca de extensão de direitos a homossexuais, esse surge inicialmente na plataforma de 1984, ainda que de maneira quase despercebida. Defendendo a responsabilidade do governo com a obtenção de direitos de minorias, o partido inclui indivíduos que foram historicamente impedidos do pleno exercício da cidadania por conta da sua orientação sexual.

Por fim, esse primeiro período caracteriza-se, também, pela inserção do tema da posse de armas de fogo. A plataforma de 1968 defende um controle federal "toward putting the weapons of wantom violence beyond the reach of criminal and irresonsible hands". Em 1976, o posicionamento do partido seria mais explícito: "Handguns simplify and intensify violent crime. Ways must be found to curtail the availability of these weapons".

Assim, nota-se que esse primeiro momento das plataformas democratas é caracterizado por posicionamentos notadamente liberais. Inicialmente o debate está marcado pelas questões das minorias: mulheres, negros e imigrantes. Apesar do hiato representado pela plataforma de 1964 - com a recusa democrata às políticas de cotas - todas as plataformas democratas valorizariam um amplo papel do governo para a ascensão dessas minorias, seja por meio de tratamento preferencial, seja por meio de legislações protecionistas, seja ainda por meio de maiores oportunidades. Há uma constante valorização da diversidade que constitui a sociedade norte-americana e uma preocupação com a unidade nacional que deveria ser realizada através do reconhecimento desse multiculturalismo.

Entretanto, o segundo momento (1996-2004) define-se por um período de inflexão conservadora. Há uma maior preocupação com valores morais e com uma espécie de uniformização da sociedade norte-americana por meio da disciplina e do "caráter". Isso se traduz nas áreas da imigração, educação e gravidez, entre outras. Pela primeira vez há a defesa recorrente do papel da religião cristã na sociedade norte-americana. Também pela primeira vez o partido iria enfatizar a necessidade de regulação de certos veículos de entretenimento com o objetivo de moralizar a sociedade. A área da educação passa a ser enfatizada a partir da necessidade de disciplina, respeito e ordem. Nesse sentido, valoriza-se uma relativa uniformização. As plataformas privilegiariam conceitos como valores, caráter e responsabilidade individual em vez da valorização da diversidade e do multiculturalismo como nas plataformas anteriores. A plataforma de 1996 é emblemática a respeito desse viés conservador: "Teaching good values, strong character, and the responsibilities of citizenship must be an essential part of American education". A mesma plataforma acrescenta ainda: "We must help schools set the highest standards for good behavior and discipline in our schools. Children cannot learn - and teachers cannot teach without order in the classroom". Em 2000, o partido defenderia um "renewed focus" em disciplina e caráter nas escolas onde cada uma deveria instaurar "strict, firm, and fair discipline policies". Ao contrário de programas sobre estudos étnicos como defendidos no período anterior, a plataforma de 2000 defende um currículo que contemple educação democrática e cívica. Por fim, em 2004, defenderia como ensinamentos fundamentais das escolas, a cidadania, a responsabilidade e "good values".

Esse segundo período é marcado também por posicionamentos mais conservadores acerca da imigração, que passa a ser tratada como uma questão de 
segurança e não mais como uma questão social. Em 1996 o partido defende o fechamento das fronteiras, maiores deportações, o fim do trabalho ilegal, o fim de benefícios para imigrantes ilegais e legais (sponsors devem financiar esses últimos) e a diminuição da entrada de imigrantes ilegais aos quais relaciona com tráfico de drogas e crimes. Ao mesmo tempo, essa mesma plataforma advoga para que não sejam feitas divisões étnicas e culturais: "However, as we work to stop illegal immigration, we call on all Americans to avoid the temptation to use this issue to divide people from each other". No entanto, coloca-se contra programas bilíngues - a ênfase recai no aprendizado do inglês pelos imigrantes. Assim, se antes a sociedade deveria se moldar para se adequar a diversidade étnica e cultural por meio de programas e serviços; agora o indivíduo é quem deve se moldar para se adequar ao "padrão" american way of life.

No que tange à gravidez na adolescência, o partido passa a traduzir uma concepção mais moralista. Em 1996, por exemplo, defende uma campanha nacional de prevenção a partir do papel do governo, da comunidade e de líderes religiosos que enfatizariam a abstinência e demandaria responsabilidade a esses adolescentes. Além disso, afirmaria a necessidade de se "ensinar" o "erro" de se engravidar antes do casamento.

Esse período conta com a primazia da religião nas plataformas. A própria linguagem, utilizando-se recorrentemente de palavras como "Deus", "fé" e "religião" demonstram essa inflexão. A plataforma de 1996, por exemplo, defende o direito de expressar a religião cristã em público e enfatiza a relação entre religião, fé e a história dos Estados Unidos como sendo um constitutivo do outro. Nesse sentido, há ainda uma valorização das instituições religiosas e de caridade e o papel dessas no combate aos problemas sociais como drogas, violência e pobreza. Por fim, relativo à posse de armas de fogo, pela primeira e única vez na análise das plataformas, o Partido Democrata defende a posse de armas sem mencionar controles legislativos.

Assim, esse é um período cujas plataformas fazem uma inflexão conservadora ao enfatizar a moralidade, a disciplina e a responsabilidade individual. Além disso, trazem temas novos como a questão da religião, das instituições de caridade e de entretenimento; e trocam de posicionamentos em diversas áreas como armas de fogo, imigração, educação e gravidez. Ainda assim, o PD mantém alguns posicionamentos liberais. Há a valorização de posicionamentos liberais no que diz respeito às questões raciais, ao aborto, à família, homossexuais e minorias, por exemplo. É importante mencionar, desse modo, que essas plataformas representam a disputa entre diferentes grupos ideológicos no partido. Conforme o Partido Democrata argumenta na plataforma de 2004: "Members of our party have deeply held and differing views on some matters of conscience and faith. We view diversity as a source of strenght".

Por fim, o terceiro período (2008-2012) caracteriza-se pelo retorno ao liberalismo. No que tange à educação, se retoma a valorização da diversidade e do multiculturalismo por meio da defesa de posicionamentos como a revitalização de línguas indígenas, programas bilíngues e o ensino de uma segunda língua obrigatória nas escolas públicas. Referente ao homossexualismo, nota-se uma postura mais afirmativa e concreta a partir de um posicionamento contrário à política do “don't ask, don't tell”" nas forças armadas e ao DOMA (Defense of Marriage Act), alegando proteções, benefícios e responsabilidades de "todas as famílias", incluso as de mesmo sexo. Relativo à imigração, o partido defende uma reforma imigratória mais "humana", que valorize benefícios e proteções aos imigrantes, um processo de naturalização mais fácil e acessível e um projeto de cidadania automática para imigrantes ilegais. A plataforma de 2008, ainda que valorize a segurança e a proteção das fronteiras, defende o fim das divisões e dos "medos infundados" na sociedade norte-americana. Por fim, preconiza a 
ajuda para maior desenvolvimento de países que enviam imigrantes. Nesse sentido, o tratamento da imigração passa a ser mais holístico - entende-se que é um problema global e que as responsabilidades devem ser compartilhadas. Por fim, o partido retornaria a defender uma ampla gama de serviços e programas para adolescentes com ênfase na redução de gravidez indesejada, incluindo orientação sexual e aborto.

\section{Análise comparativa das plataformas Republicanas e Democratas}

O gráfico conjunto dos posicionamentos dos dois partidos políticos acerca das questões sociais é bastante emblemático no que tange a suposta polarização partidária (Gráfico 3). Nele, essa hipótese é confirmada. O PR possui dois ápices invertidos: um primeiro momento caracterizado por posicionamentos consistentemente liberais e um segundo momento, a partir de 1972, caracterizado pela ascendência constante de posicinamentos conservadores. Enquanto no primeiro momento o PR situa-se no espectro liberal do gráfico apresentado, inclusive refletindo médias mais liberais que o próprio PD em certos períodos, no segundo momento há uma importante ascensão da orientação conservadora, culminando com a plataforma de 1984 e mantendo uma constância conservadora a partir de então. Percebe-se, portanto, uma clara ascensão e posterior manutenção de posicionamentos conservadores a partir da década de 1970 por parte do PR. O PD, ao contrário, mantém-se no espectro liberal do gráfico, salvo o período de exceção caracterizado pela plataforama de 1996 - o único momento em que o partido pontua dentro do espectro conservador. Desse modo, nota-se uma clara aproximação de posicionamentos nos primeiros anos analisados - 1936 a 1972 - caracterizado por posicionamentos liberais por parte de ambos os partidos políticos. Nas questões sociais, o discurso acerca de uma homogeneização ideológica entre os partidos é bastante visível. Do mesmo modo, é também bastante visível a polarização partidária que se segue a partir de então. Nesse sentido, nota-se nas duas últimas plataformas (2008 e 2012), a maior polarização já presenciada, sobressaindo-se inclusive à polarização que se deu na década de 1980 . Do mesmo modo que a hipótese acerca da polarização partidária pode ser verificada com bastante clareza, a idéia de ascensão conservadora é também visível.

Gráfico 3 - Médias questões sociais - Partido Democrata e Republicano

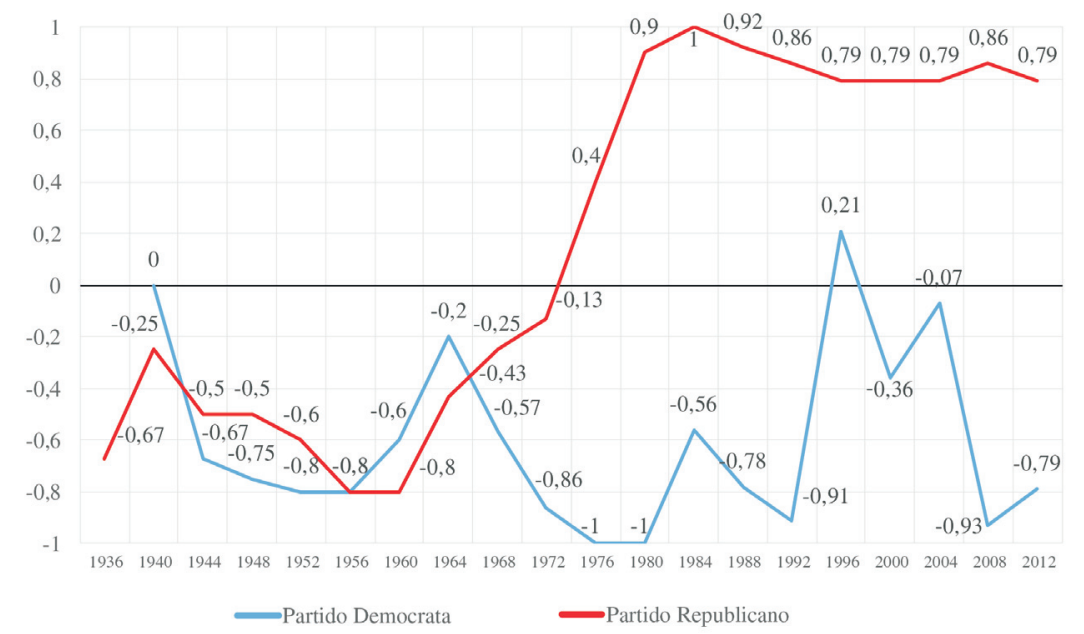

Fonte: A autora, com base nas plataformas dos Partidos Democrata e Republicano. 


\section{Conclusões}

Fenômeno de crescente importância no debate acadêmico norte-americano atual, a suposta polarização partidária tem sido objeto de inúmeros estudos, conforme já apontado. As análises feitas, ao associar o posicionamento de congressistas com a polarização partidária, caracteriza o partido político unicamente a partir dessas lideranças políticas. É importante lembrar que os partidos norte-americanos são instituições bastante complexas, caracterizadas por um certo horizontalismo hierárquico e completa descentralização, o que permite uma ampla gama de atores na sua condução: delegados, presidente, congressistas, membros associados, braços intelectuais e estratéticos (think tanks) etc.

Esse trabalho, diferentemente dessas análises, buscou apresentar uma forma diferente de se analisar o fenômeno da polarização partidária. É importante mencionar que de modo algum busca sobrepor-se aos estudos já feitos ou subjugá-los; ao contrário, busca ser um complemento a partir de lacunas que foram evidenciadas. Desse modo, buscou-se inicialmente fazer uma apresentação das duas mais importantes correntes ideológicas nos EUA - o liberalismo e o conservadorismo - a partir de como esses conceitos foram sendo construídos, seja por determinadas lideranças políticas que trouxeram à superfície preceitos progressistas, como no caso do liberalismo, seja por certos grupos de indivíduos outsiders dos partidos políticos, que conscientemente se articularam para levar para o campo da política a sua visão de mundo, como no caso do conservadorismo. Assim, foi feita uma releitura de como esses movimentos foram sendo construídos e se aproximando do que hoje se entende por conservadorismo e por liberalismo nos EUA a partir de determinados pilares e de visões de mundo distintas. Explicitou-se, nesse sentido, quais seriam os mais importantes preceitos conservadores e liberais e como que são explicitados no meio político.

Apropriando-se de uma corrente de estudos que percebe nas plataformas o melhor retrato ideológico do partido político (justamente por ser esse o único documento passível de ser atribuído ao partido como um todo - percebendo-o como um aglomerado de lideranças formais ou não); buscou-se verificar o posicionamento do partido a partir de uma categoria em específico: questões sociais. Nesse sentido, foi feita uma análise dos posicionamentos dos partidos a partir de indicadores que contam com a presença/ausência de preceitos liberais ou conservadores e a gradação desses preceitos ao longo dos anos a partir de escalas de quantificação.

Desse modo, o trabalho aqui apresentado é fruto de um exaustivo trabalho de interpretação e de leitura e releitura de cada uma das 40 plataformas analisadas. Esses documentos são bastante extensos (contando com plataformas que beiram 100 páginas), complexos (com temas que abarcam áreas diversas como defesa, agricultura e economia) e que dizem respeito a uma determinada realidade que obviamente não é a brasileira. Ao mesmo tempo, esses documentos propiciam um retrato ideológico partidário passível de ser comparado ao longo dos anos de maneira bastante precisa já que são formalmente atribuídos ao partido e endossados por todos - tácita ou formalmente. Nesse sentido, se buscou ser o mais objetiva possível na interpretação das plataformas. O resultado é, assim, muito provavelmente uma contribuição importante tanto para a academia brasileira quanto para a academia norte-americana no sentido de codificar escalas de posicionamento em áreas distintas a partir das 40 plataformas analisadas o que corresponde a quase um século de história política nos Estados Unidos. Nesse sentido, se pode observar como certos temas foram sendo trazidos para o debate político ao longo dos anos, como os partidos foram 
se posicionando nesses temas e como houveram inflexões nesses mesmos posicionamentos.

Como se pode observar, portanto, os dois partidos analisados não tendem a seguir um padrão único e linear. Ou seja, uma vez que manifestam-se contra ações afirmativas em uma dada plataforma, não tendem a seguir esse mesmo padrão necessariamente nos anos seguintes ou mesmo a associá-lo com outros posicionamentos de mesma percepção ideológica de modo coerente. Assim, esses documentos nos mostram que há inflexões, tanto no que diz respeito ao posicionamento explicitado ao longo dos anos referente a um determinado tema, quanto aos posicionamentos frente a diferentes temas e áreas - nem sempre ideologicamente congruentes entre si.

A análise ainda nos mostra uma certa convergência de plataformas mais liberais ou mais conservadoras com a própria construção desses conceitos e de como tais plataformas são expostas a partir de análises históricas. De modo mais específico, percebe-se uma importante inflexão liberal por parte do PR nas plataformas anteriores a 1964, justamente o período caracterizado nos Estados Unidos como o "me too politics" (Fiorina, 1999) a partir da similitude ideológica entre os partidos. Da mesma forma, percebe-se um pico conservador por parte do PR no ano de 1964 - ano em que Barry Goldwater foi "fabricado" conscientemente por um certo grupo de conservadores outsiders. Novamente, há uma ascensão conservadora e a relativa permanência dela a partir de 1980 ano em que Reagan, ele próprio um expoente conservador e durante muito tempo também outsider do meio político, ascende carregando consigo as várias vertentes conservadoras para o partido. Por fim, a análise das plataformas nos indica ainda uma convergência com a literatura explicitada anteriormente, que apontava para uma disputa de grupos e de facções ideológicas no PD na década de 1990 - os democratas tradicionais (liberais) e os democratas revisionistas (mais conservadores). Assim como no caso do PR, esse período é bastante evidente nos gráficos apresentados, refletindo uma inflexão conservadora por parte do PD. Além disso, expressa uma espécie de "hiato" no que vinha sendo um padrão relativamente homogêneo, caracterizado por posicionamentos liberais. Com esses resultados, o estudo contribui empiricamente para o que a literatura já apontava.

Ao fim, a análise corrobora a hipótese da polarização partidária. De fato, há um distanciamento ideológico entre esses partidos, causado, sobretudo, por uma importante inflexão conservadora pelo Partido Republicano. Ainda que de forma muito incipiente e possivelmente com lacunas explicativas, o trabalho elucidou um fenômeno importante nos EUA e mesmo na Ciência Política, qual seja, o atual distanciamento dos partidos do centro do espectro político, contradizendo um importante cânone de uma das mais importantes correntes teóricas. De fato, o que os estudos recentes e a análise aqui realizada nos mostram é uma atual oposição entre partidos com base em visões de mundo e, consequentemente, de posicionamentos políticos. Longe de se caracterizarem por um discurso centrista ou pouco comprometido (retóricas soltas e discurso eminentemente ambíguo) com o intuito de angariar a maioria do eleitorado, os partidos norte-americanos definem-se por posicionamentos opostos e firmes, caracterizando-se por um confronto ideológico na área analisada. Resta saber se esse processo beneficia a democracia ao representar a sociedade com todas as suas idiosincrasias ou, ao contrário, prejudica a democracia por contemplar extremos nem sempre característicos da sociedade como um todo.

Camila Feix Vidal (camilafeixvidal@gmail.com) é Doutora em Ciência Política pela Universidade Federal do Rio Grande do Sul (UFRGS) e Professora do Departamento de Relações Internacionais da Universidade Federal do Rio Grande (FURG). Vínculo Institucional: Departamento de Relações Internacionais, FURG, Rio Grande, RS, Brasil. 


\section{Referências}

Aberbach, J. \& Peele, G., 2011. Crisis of Conservatism? The Republican Party, the Conservative Movement, and American Politics After Bush. Oxford: Oxford University Press.

Bell, D., 1950. O fim da ideologia. Brasília: Editora da UNB.

Brennan, M., 1995.Turning Right in the Sixties: The Conservative Capture of the GOP. Chappel Hill: The University of North Carolina Press.

Broader, D., 1972. The Party's Over: The Failure of Politics in America. New York: Harper and Row.

Budge, I.; Robertson, D. \& Hearl, D., 1987. Ideology, Strategy and Party Change: Spatial Analysis of Post-War Election Programmes in 19 Democracies. Cambridge, UK: Cambridge University Press.

Critchlow, D., 2007. The Conservative Ascendancy: How the GOP Right Made Political History. Cambridge, MA: Harvard University Press.

Crotty, W., 1984. American Parties in Decline. Boston: Little Brown and Company.

D’Alessandro, M., 2013. Las Plataformas Electorales en la Argentina Moderna. America Latina Hoy, 65, pp.107-139. DOI: 10.14201/alh201365107139

Downs, A., 1999. Uma teoria econômica da democracia. São Paulo: Edusp.

Feinstein, B. \& Schickler, E., 2008. Platforms and Partners: The Civil Rights Realignment Reconsidered. Studies in American Political Development, 22, pp.1-31.

Fiorina, M.P., 1999. What Happened to the Medium Voter? In MIT Conference on Parties and Congress. Cambridge, MA.

Fiorina, M.P. \& Abrams, S.J., 2008. Political Polarization in the American Public. Annual Review of Political Science, 11, pp.563-588. DOI: 10.1146/annurev.polisci.11.053106.153836

Gifford, L. \& Williams, D., 2012. The Right Side of the Sixties: Reexamining Conservatism's Decade of Transformation. New York: Palgrave Macmillan.

Gottfried, P., 2007. Conservatism in America: Making Sense of the American Right. New York: Pallgrave Macmillan.

Green, D., 1992. The Language of Politics in America. London: Cornell University Press.

Himmelstein, J., 1989. To The Right: The Transformation of American Conservatism. Berkeley: University of California Press. Hunter, J.D. \& Wolfe, A., 2006. Is There a Culture War? Washington, DC: Brookings Institution Press.

Koster, W.; Achterberg, P. \& Van Der Wall, J., 2012. The New Right and the Welfare State: The Electoral Relevance of Welfare Chauvinism and Welfare Populism in the Netherlands. International Political Science Review, 34(1), pp.3-20. DOI: $10.1177 / 0192512112455443$

Lange, S., 2007. A New Winning Formula? The Programmatic Appeal of the Radical Right. Party Politics, 13(4), pp.411-425. DOI: $10.1177 / 1354068807075943$

Laver, M. \& Garry, J., 2000. Estimating Policy Positions from Political Texts. American Journal of Political Science, 44(3), pp.619-634. DOI: 10.2307/2669268

Levendusky, M., 2009. The Partisan Sort. Chicago: The University of Chicago Press.

Mann, T.E. \& Ornstein, N.J., 2012. It's Even Worse Than It Looks. New York: Basic Books.

Masket, S., 2012. No Middle Ground: How Informal Party Organizations Control Nominations and Polarize Legislatures. Michigan: The University of Michigan Press.

McCarthy, N.; Poole, K. \& Rosenthal, H., 2006. Polarized America. London: The MIT Press.

Nash, G.H., 2009. Reappraising the Right: The Past and Future of American Conservatism. Wilmington: ISI Books. 1996. The Conservative Intellectual Movement in America Since 1945. Wilmington: Intercollegiate Studies Institute.

Philips-Fein, K., 2009. Invisible Hands: The Making of the Conservative Movement from the New Deal to Reagan. New York: W.W. Norton and Company.

Pierson, P. \& Hacker, J., 2005. Off Center: The Republican Revolution and the Erosion of American Democracy. New Haven: Yale University Press.

Pierson, P. \& Skocpol, T., 2007. The Transformation of American Politics: Activist Government and the Rise of Conservatism. Princeton: Princeton University Press.

Pocock, J.G.A., 2003. Linguagens do ideário político. São Paulo: Edusp.

Pomper, G., 1967. "If elected, I promise": American Party Platforms. Midwest Journal of Political Science, 11(3), pp.318-352. DOI: $10.2307 / 2108616$

Poole, K. \& Rosenthal, H., 1985. A Spatial Model for Legislative Roll Call Analysis. American Journal of Political Science, 29(2), pp.357-384. DOI: $10.2307 / 2111172$ 1984. The Polarization of American Politics. The Journal of Politics, 46(4), pp.1061-1079.

Powel, G.B., 2012. Representation in Context: Election Laws and Ideological Congruence Between Citizens and Government. Discurso proferido na American Political Science Association.

Prior, M., 2013. Media and Political Polarization. Annual Review of Political Science, 16, pp.101-127. DOI: 10.1146/annurev-polisci-100711-135242

Rossiter, C., 1962. Conservatism in America: The Thankless Persuasion. New York: Vintage Books.

Schneider, G.L., 2009. The Conservative Century: From Reaction to Revolution. Lanham: Rowman and Littlefield Publishers.

Seliger, M., 1976. Ideology and Politics. Birkenhead: Wilmer Brothers.

Sinclair, B., 2006. Party Wars. Oklahoma: Oklahoma University Press. 
Thompson, M., 2007. Confronting the New Conservatism: The Rise of the Right in America. New York: New York University Press.

Vidal, C.F., 2016. Polarização partidária e ascensão conservadora: uma análise das plataformas nacionais Republicanas e Democratas nos Estados Unidos (1936-2012). Tese de Doutorado. Porto Alegre: UFRGS.

Wattenberg, M., 1998. The Decline of American Political Parties. Cambridge, MA: Harvard University Press.

\section{Artigos de jornais}

Fiorina, M.P., 2014. Americans Have Not Become more Politically Polarized. The Washington Post, 23 jun.

Mann, T.E., 2014. Admit It, Political Scientists: Politics Is More Broken Than Ever. The Atlantic, 26 May. Disponível em: http://www.theatlantic.com/politics/print/2014/05/dysfunction/371544/. Acesso em: 30 jan. 2018.

\section{Outras fontes}

American Political Science Association, 1950. Toward a More Responsible Two Party System: A Report of the Committee on Political Parties. New York: Rinehart and Co.

CMP-MPG. Manifesto Project Database. Disponível em https://manifesto-project.wzb.eu/. Acesso em: 30 jan. 2018.

Partido Democrata. Democratic Party National Platforms. Disponível em: http://www.presidency.ucsb.edu/. Acesso em: 30 jan. 2018.

Partido Republicano. Republican Party National Platforms. Disponível em: http://www.presidency.ucsb.edu/. Acesso em: 30 jan. 2018.

Extreme Politics: Party Polarization and Social Issues in the United States (1936-2012)

ABSTRACT Introduction: This article dedicates itself to the study of the political polarization's social issues in the United States between 1936-2012. Through the use of platforms at the national level, this study aims to verify the supposedly polarization between the two main political parties in this country and to contribute to new research methods in the study of political parties. Methods: The Republican and Democratic national platforms were used as an indicative of party ideological position. As such, through the creation of categories and, afterwards, scales of gradation built through informational programs such as SPSS, ManyEyes/IBM and NVivo, the political positioning of these two parties were mesured and compared seeking to verify ideological approximations and distancing. Results: The results show us that, indeed, thre is a party polarization in recent period when referring to social issues caused, mainly, by a conservative ascendancy by the Republican party that began in the 1970s. Discussion: Result of an exaustive work of reading, interpreting and coding of 40 documents that embrace almost a century of history, this article contributes to a greater comprehension of a recent political and social phenomena of great importance for Political Science.

KEYWORDS: Ideological Polarization; Conservatism; United States; Republican Party; Democratic Party.

This is an Open Access article distributed under the terms of the Creative Commons Attribution Non-Commercial License which permits unrestricted non-commercial use, distribution, and reproduction in any medium provided the original work is properly cited. 


\section{Apêndice}

Quadro 1A - Indicadores de presença/ausência de preceitos Conservadores e Liberais: Quantificação por meio de escalas entre +1 e -1

\section{Tema}

1 Gênero e feminismo (ERA)

2 Aborto

3 Homossexualismo

4 Imigração

5 Família

6 Educação - currículo

7 Gravidez na adolescência orientação sexual

8 Entretenimento (pornografia e conteúdo de TV para crianças, por exemplo)

\section{Indicadores}

1.1 Abstenção do governo federal - assunto a ser tratado pelos estados; ou menção favorável ao $\operatorname{EPEW(Equal~Pay~for~Equal~Work)~tão~somente,~bem~como~ao~}$ crescimento econômico para maiores conquistas $(+1)$

1.2 A plataforma não faz menção (0)

1.3 Defesa de uma rede de proteção e de extensão de direitos pelo governo federal que não se restringe ao EPEW, mas que abarca legislações como o ERA (-1)

2.1 A plataforma mostra-se Pro-life (contra Roe vs. Wade) (+1)

2.2 A plataforma não faz menção (0)

2.3 A plataforma mostra-se Pro-choice (a favor de Roe vs. Wade) (-1)

3.1 Relativa segregação de direitos civis - a plataforma defende a diminuição de direitos civis já conquistados ou advoga pela ingerência estadual e local sobre o assunto (+1)

3.2 A plataforma não faz menção $(0)$

3.3 Inclusão de direitos civis - a plataforma defende a não discriminação e/ou manifesta-se a favor da inclusão de direitos civis $(-1)$

4.1 A plataforma enfatiza a diminuição de direitos a imigrantes legais e/ou deportação dos ilegais. Relativo às fronteiras, a plataforma advoga pela restrição da entrada (contra a política de reunificação da família, por ex.) (+1)

4.2 A plataforma não faz menção (0)

4.3 A plataforma enfatiza a extensão de direitos a imigrantes legais ou ilegais já vivendo nos EUA (política de acolhimento). Relativo às fronteiras, aceita um certo fluxo, como por exemplo, no que concerne a reunificação familiar (-1)

5.1 Ênfase nos valores tradicionais e na moralidade - fortalecimento por meio da ação direta do governo federal (legislações mais severas relativo ao divórcio e DOMA, por ex.) ou de instituições faith based na manutenção da família e do casamento tradicionais $(+1)$

5.2 A plataforma não faz menção (0)

5.3 Ênfase nas condições práticas de manutenção - fortalecimento por meio de programas federais (day care, por ex.) para a manutenção da família; e ou da valorização de uma definição de família que inclua casais homossexuais (-1)

6.1 Ênfase na educação cívica, na disciplina, na ordem e/ou na história dos Estados Unidos, constituição, símbolos etc. (hino, bandeira, pledge of allegiance etc.) nacionalismo $(+1)$

6.2 A plataforma não faz menção (0)

6.3 Ênfase em temas como homossexualismo e orientação sexual e/ou na discussão sobre minorias (latinos, negros etc.) - multiculturalismo (-1)

7.1 A plataforma mostra-se contrária à orientação sexual e/ou defende a abstinência até o casamento $(+1)$

7.2 A plataforma não faz menção $(0)$

7.3 A plataforma mostra-se a favor de orientação sexual, seja por meio da escola, seja por meio de programas e recursos federais (-1)

8.1 Regulação do governo federal (+1)

8.2 A plataforma não faz menção (0)

8.3 Abstenção do governo federal (-1) 
9 Religião (Cristã)

11 Questão racial - Civil Rights

14 Child Care e Day Care I $^{\mathrm{I}}$ (relativo ao debate de gênero) (faith based institutions)
13 Armas de fogo

9.1 É expressada como uma extensão do governo federal e como característica da sociedade - seu fortalecimento dá-se por meio da defesa e valorização dos seus símbolos e rituais nas dependências e extensões do governo federal (+3)

9.2 A plataforma não faz menção (0)

9.3 É expressada de maneira a situar-se em separado do governo federal - respeito ao multiculturalismo e às diversas religiões (-1)

10 Religião e instituições voluntárias

10.1 A plataforma defende a atuação dessas como um "braço" do governo federal, podendo vir a substituir-lhe funções humanitárias e sociais $(+1)$

10.2 A plataforma não faz menção (0)

10.3 A plataforma entende que essas trabalham em conjunto ou que são orientadas pelo governo federal, mas não substituem o papel desse (-1)

11.1 Maiores direitos por meio de legislação estadual e/ou do crescimento econômico - sem envolvimento do governo federal (+1)

11.2 A plataforma não faz menção (0)

11.3 Legislação deve ser feita pelo governo federal (-1)

12 Ações afirmativas para minorias

12.1 A plataforma desqualifica ações afirmativas $(+1)$

12.1 A plataforma não faz menção (0)

12.3 A plataforma valoriza ações afirmativas (-1)

13.1 Ênfase na desregulamentação federal - é direito individual (+1)

13.2 A plataforma não faz menção (0)

13.3 Ênfase na regulamentação federal - é dever do governo federal

14.1 A plataforma enfatiza o papel do stado, município, instituições religiosas, privadas ou voluntárias $(+1)$

14.2 A plataforma não faz menção (0)

14.3 A plataforma enfatiza o papel do governo federal na construção e/ou na distribuição de recursos (-1)

Fonte: A autora.

${ }^{\mathrm{I}}$ Refere-se à instituições educacionais voltadas para crianças e bebês. 